\title{
New ophthalmologic imaging techniques for detection and monitoring of neurodegenerative changes in diabetes: a systematic review
}

Citation for published version (APA):

de Clerck, E. E. B., Schouten, J. S. A. G., Berendschot, T. T. J. M., Kessels, A. G. H., Nuijts, R. M. M. A., Beckers, H. J. M., Schram, M. T., Stehouwer, C. D. A., \& Webers, C. A. B. (2015). New ophthalmologic imaging techniques for detection and monitoring of neurodegenerative changes in diabetes: a systematic review. The Lancet Diabetes \& Endocrinology, 3(8), 653-663. https://doi.org/10.1016/S22138587(15)00136-9

Document status and date:

Published: 01/01/2015

DOI:

10.1016/S2213-8587(15)00136-9

Document Version:

Publisher's PDF, also known as Version of record

\section{Document license:}

Taverne

Please check the document version of this publication:

- A submitted manuscript is the version of the article upon submission and before peer-review. There can be important differences between the submitted version and the official published version of record.

People interested in the research are advised to contact the author for the final version of the publication, or visit the DOI to the publisher's website.

- The final author version and the galley proof are versions of the publication after peer review.

- The final published version features the final layout of the paper including the volume, issue and page numbers.

Link to publication

\footnotetext{
General rights rights.

- You may freely distribute the URL identifying the publication in the public portal. please follow below link for the End User Agreement:

www.umlib.nl/taverne-license

Take down policy

If you believe that this document breaches copyright please contact us at:

repository@maastrichtuniversity.nl

providing details and we will investigate your claim.
}

Copyright and moral rights for the publications made accessible in the public portal are retained by the authors and/or other copyright owners and it is a condition of accessing publications that users recognise and abide by the legal requirements associated with these

- Users may download and print one copy of any publication from the public portal for the purpose of private study or research.

- You may not further distribute the material or use it for any profit-making activity or commercial gain

If the publication is distributed under the terms of Article $25 \mathrm{fa}$ of the Dutch Copyright Act, indicated by the "Taverne" license above, 


\title{
New ophthalmologic imaging techniques for detection and monitoring of neurodegenerative changes in diabetes: a systematic review

\author{
Eline E B De Clerck, Jan S A G Schouten, Tos TJ M Berendschot, Alfons G H Kessels, Rudy M M A Nuijts, Henny J M Beckers, Miranda T Schram, \\ Coen D A Stehouwer, Carroll A B Webers
}

Optical coherence tomography (OCT) of the retina and around the optic nerve head and corneal confocal microscopy (CCM) are non-invasive and repeatable techniques that can quantify ocular neurodegenerative changes in individuals with diabetes. We systematically reviewed studies of ocular neurodegenerative changes in adults with type 1 or type 2 diabetes and noted changes in the retina, the optic nerve head, and the cornea. Of the 30 studies that met our inclusion criteria, 14 used OCT and 16 used CCM to assess ocular neurodegenerative changes. Even in the absence of diabetic retinopathy, several layers in the retina and the mean retinal nerve fibre layer around the optic nerve head were significantly thinner $(-5 \cdot 36 \mu \mathrm{m}$ [95\% CI $-7 \cdot 13$ to $-3 \cdot 58])$ in individuals with type 2 diabetes compared with individuals without diabetes. In individuals with type 1 diabetes without retinopathy none of the intraretinal layer thicknesses were significantly reduced compared with individuals without diabetes. In the absence of diabetic polyneuropathy, individuals with type 2 diabetes had a lower nerve density (nerve branch density: $-1 \cdot 10 / \mathrm{mm}^{2}$ [95\% CI $-4 \cdot 22$ to $\left.2 \cdot 02\right]$ ) nerve fibre density: $-5 \cdot 80 / \mathrm{mm}^{2}[-8.06$ to $-3 \cdot 54]$, and nerve fibre length: $-4.00 \mathrm{~mm} / \mathrm{mm}^{2}[-5.93$ to $\left.-2 \cdot 07]\right)$ in the subbasal nerve plexus of the cornea than individuals without diabetes. Individuals with type 1 diabetes without polyneuropathy also had a lower nerve density (nerve branch density: $-7 \cdot 74 / \mathrm{mm}^{2}$ [95\% CI $-14 \cdot 13$ to $\left.-1 \cdot 34\right]$, nerve fibre density: $-2.68 / \mathrm{mm}^{2}[-5.56$ to $0 \cdot 20]$ ), and nerve fibre length: $-2.58 \mathrm{~mm} / \mathrm{mm}^{2}[-3.94$ to $\left.-1 \cdot 21]\right)$. Ocular neurodegenerative changes are more evident when diabetic retinopathy or polyneuropathy is present. OCT and CCM are potentially useful, in addition to conventional clinical methods, to assess diabetic neurodegenerative changes Additional research is needed to determine their incremental benefit and to standardise procedures before the application of OCT and CCM in daily practice.

\section{Introduction}

Diabetic retinopathy and diabetic polyneuropathy are major complications of diabetes that can start insidiously, with few or no symptoms. ${ }^{1}$ Improved assessments in clinical practice are urgently needed to predict onset and monitor progression of diabetic retinopathy ${ }^{2}$ and diabetic polyneuropathy. ${ }^{3,4}$

Diabetic retinopathy is widely thought to be the earliest microvascular complication of diabetes, which is typically detected by ophthalmoscopic examination. However, retinal neurodegenerative changes - notably glial activation and neuronal apoptosis leading to a thinning of the neuronal layers in the retina-also occur in the eyes of individuals with diabetes at an early stage of diabetic retinopathy, even when microvascular lesions cannot be detected by ophthalmologic examination..$^{5-8}$ Because early diabetic retinopathy includes a neurodegenerative component, the assessment of diabetic retinopathy should also quantify these structural changes in the retina.

Investigations of diabetic polyneuropathy are commonly based on (semi-)quantitative sensory tests, electrophysiology, or examination of skin biopsy samples. However, the onset of diabetic polyneuropathy is difficult to detect by electrophysiology ${ }^{9}$ and vibration perception tests, ${ }^{10}$ which only quantify large fibre deficits. The earliest nerve damage occurs at the level of the small nerve fibres. ${ }^{11}$ These fibres can be assessed by thermal and pain perception tests, but these measures are extremely variable. ${ }^{10,12}$ Skin biopsy and sural nerve biopsy are invasive procedures and might not be suitable for long-term follow-up or clinical trials.

Two new ophthalmological imaging techniques, optical coherence tomography (OCT) and corneal confocal microscopy (CCM), could be of value to identify early neurodegenerative changes in individuals with diabetes, and to monitor changes over time. Both techniques are non-invasive, repeatable, and user-friendly. ${ }^{13-18}$ Several software programs exist to measure ocular neurodegenerative changes. ${ }^{19-26}$

OCT provides 2-dimensional high-resolution $(5-10 \mu \mathrm{m})$ cross-sectional scans of the retina, showing an amount of detail that resembles histological specimens (figure 1)..$^{27,28}$ OCT can quantify the thickness of separate retinal layers in the macula and around the optic nerve head. Segmentation of intraretinal layers showed thinning in the earliest stages of diabetic retinopathy. ${ }^{29-31}$ OCT could help clinically to detect early retinal neurodegeneration to define at-risk patients and to plan preventive therapy before the development of vascular lesions detectable by ophthalmoscopy. Furthermore, OCT can be used to monitor progression of diabetic retinopathy and to assess therapeutic efficacy of existing or new treatment methods. ${ }^{32-34}$

CCM can directly visualise and quantify the nerve fibres of the cornea. The transparency of the cornea enables visualisation of the subbasal nerve plexus by twodimensional scans (figure 2), real-time mapping of several images, or by 3-dimensional images. ${ }^{35}$ These
Lancet Diabetes Endocrinol 2015 3: 653-63

Published Online July 14, 2015 http://dx.doi.org/10.1016/ S2213-8587(15)00136-9 Department of Ophthalmology, Maastricht University Medical Center + Maastricht, Netherlands (E E B De Clerck MD, JSA G Schouten MD, TTJ M Berendschot PhD Prof R M M A Nuijts MD HJ M Beckers MD, Prof ( A B Webers MD); Department of Anesthesiology and Pain Medicine, Maastricht University Medical Center + Maastricht, Netherlands (A G H Kessels MD); and Department of Internal Medicine and Cardiovascular Research Institute, Maastricht University Medical Center + Maastricht, Netherlands (MT Schram PhD, Prof C D A Stehouwer MD) Correspondence to: Dr Eline E B De Clerck, University Eye Clinic Maastricht, PO Box 5800, NL-6202 AZ Maastricht, The Netherlands eline.de.clerck@mumc.nl 


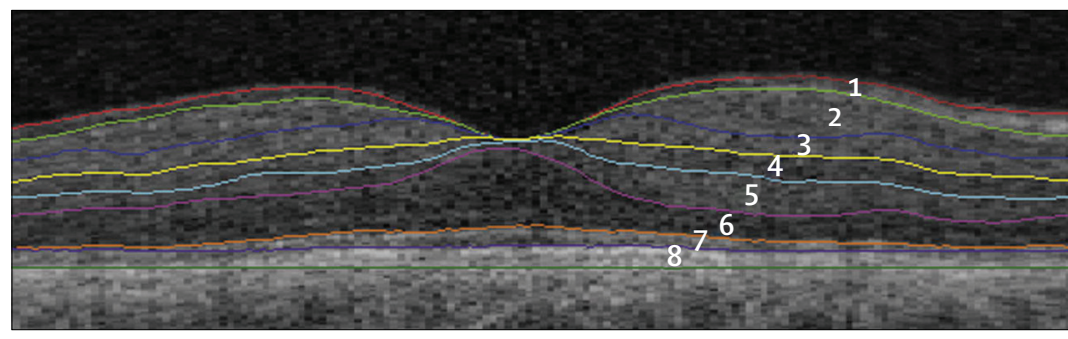

Figure 1: Optical coherence tomography of the macula showing the distinct retinal layers Layer 1=retinal nerve fibre layer. Layer 2=ganglion cell layer. Layer 3=inner plexiform layer. Layer 4=inner nuclear layer. Layer $5=$ outer plexiform layer. Layer $6=$ outer nuclear layer + inner segments (photoreceptors). Layer $7=$ outer segments (photoreceptors). Layer $8=$ retinal pigment epithelium. Reproduced with permission from van Dijk and colleagues. ${ }^{27}$

See Online for appendix
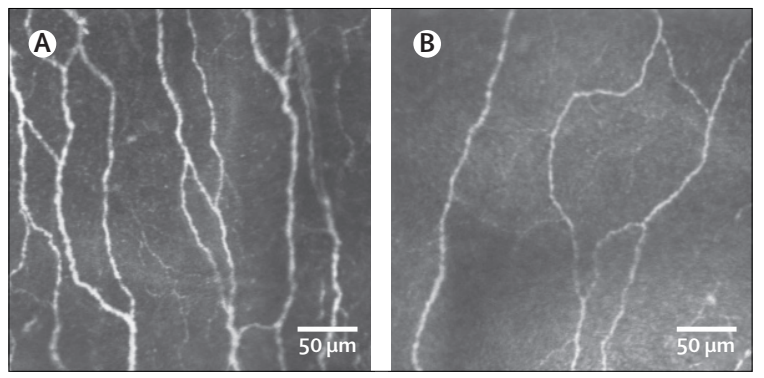

Figure 2: Confocal microscopy of the cornea

Single image from the subbasal nerve plexus of the cornea in an individual without diabetes $(A)$ and in an individual with diabetes showing a decrease in the nerve density and nerve length, and an increase in the tortuosity (B).

images can be made with or without making contact with the cornea. ${ }^{36}$ All layers can be imaged at a cellular level at a resolution of $1-2 \mu \mathrm{m} .^{37} \mathrm{CCM}$ can detect changes in nerve density, nerve length, and tortuosity in individuals with diabetes. ${ }^{38-40}$ CCM could help clinically to diagnose diabetic polyneuropathy non-invasively, and could detect biomarkers that predict the onset of polyneuropathy before changes are detected by electrophysiology and vibration perception. ${ }^{11}$ Additionally, CCM can be used to monitor progression of diabetic polyneuropathy, to assess therapeutic efficacy of existing or new treatments, and to detect regeneration of corneal nerves after intensive treatment of diabetes. ${ }^{41-43}$ However, studies of neurodegenerative changes in the eyes of individuals with diabetes have still not been systematically reviewed to define biomarkers that predict the onset and monitor progression of diabetic retinopathy and polyneuropathy.

The aim of this Review is to systematically investigate to what extent ocular neurodegenerative changes can be shown in individuals with diabetes with these ophthalmologic imaging techniques, and whether these changes can also be detected in the absence of diabetic retinopathy and diabetic polyneuropathy, as defined with classic methods.

\section{Methods}

\section{Search strategy and selection criteria}

Following the PRISMA statement and checklist, ${ }^{44,45}$ we searched Medline, the Cochrane Controlled Trials Register, and Embase and used a broad systematic search strategy according to the Cochrane collaboration (appendix pp 54-59). We searched for articles published up to Jan 20, 2015, with the terms "diabetes", "cornea”, "nerve fibers", "macula", "retinal layers", "retinal thickness", "optical coherence tomography", "colour vision", "dark adaptation", "electrooculography", "electrophysiology", "perimetry", "contrast sensitivity", "red-free photography", "optic disk", "optic nerve head", "scanning laser polarimetry", and "heidelberg retinal tomography", in English, French, German, or Dutch. The search was limited to studies in human beings. The bibliographies of included articles were screened until no new articles were found. In addition, information about possible studies was collected through personal communication with other researchers.

We included randomised controlled trials, cohort studies, prospective and retrospective case series, and case-control studies of adults ( $\geq 18$ years) with type 1 or type 2 diabetes. Included studies had to have one or more of three outcome measures. First, neurodegenerative changes in the layers of the retina-ie, changes located at the central fovea or at the foveal, the pericentral, or the peripheral area of the macula. The layers that were assessed at these locations are the retinal nerve fibre layer, ganglion cell layer, inner plexiform layer, inner nuclear layer, outer plexiform layer, photoreceptor layers (ie, outer nuclear layer, inner segments, and outer segments), retinal pigment epithelium, and the total retinal thickness. Second, neurodegenerative changes around the optic nerve head-ie, changes in retinal nerve fibre layer thickness in the mean, superior, temporal, inferior, and nasal quadrants around the optic nerve head. Third, neurodegenerative changes in the subbasal nerve plexus of the cornea-ie, changes in nerve density, nerve length, and tortuosity.

EEBDC selected the eligible studies and JSAGS checked the selection. Study selection was done in two stages. First, we screened papers by reading the title, abstract, and keywords. We excluded reviews, letters, and comments. Second, we screened the full text of eligible papers and included them if they assessed one or more of the preselected outcome measures for neurodegenerative changes in the retina, the optic nerve head, or subbasal nerve plexus of the cornea. Studies were excluded if they included individuals with clinically significant diabetic macular oedema, if they did not distinguish between type 1 and type 2 diabetes, or if they did not use an OCT device for measurements in the retina and around the optic nerve head.

\section{Data extraction and analysis}

EEBDC reviewed the studies for inclusion and quality and extracted the data. The data extraction sheet was based on the Cochrane Consumers and Communication Review Group's data extraction template. JSAGS checked the data. Disagreements were resolved by discussion between the two review authors. Studies were not blinded for the 
journal or any other aspect of the article. The data extracted were: author and year of publication, type of study, study design, country, type of diabetes, number of individuals with and without diabetes, subgroups, inclusion and exclusion criteria, method of the measurement, neurodegenerative variables studied, mean value and $95 \% \mathrm{CI}$ of the variables for individuals with and without diabetes. In addition, the age of the individuals in the study and duration of diabetes (mean [SD]) were extracted.

Methodological quality was assessed according to the Delphi list with two additional items. Table 1 describes the six domains that were assessed. These domains were assessed by a score of "Yes" (high quality), "No" (low quality), or "Unclear" (uncertain quality).

Risk of bias was assessed according to Cochrane guidelines. Figure 3 shows the four domains that were assessed. These domains were assessed by a score of "Yes" (low risk of bias), "No" (high risk of bias), or "Unclear" (uncertain risk of bias).

All pooled analyses were based on random effects models because of the differences between included studies in terms of study population, intervention, and outcomes. Statistical analyses were done with SPSS version 21. Mean neurodegenerative variables of individuals with and without diabetes were compared and the summary point estimate with $95 \%$ CIs from meta-analysis was calculated with Stata IC 12.

Subgroup analyses were done in studies quantifying ocular neurodegenerative changes by OCT of the retinal layers and around the optic nerve head making four comparisons (appendix pp 52-53). First, we established whether retinal neuronal layers were thinner in individuals with diabetes compared with individuals without diabetes. Second, we established whether retinal neuronal layers were already thinner in an early stage in individuals with diabetes without retinopathy compared with individuals without diabetes, because early diabetic retinopathy can include a neurodegenerative component. Third, in individuals with diabetes, we established whether retinal neuronal layers were thinner when retinopathy is present. Fourth, we established whether retinal neuronal layers were thinner in individuals with diabetic polyneuropathy compared with individuals without diabetes, because retinal neurodegenerative changes can be related to diabetic polyneuropathy. We did the analyses separately for type 1 and type 2 diabetes. Corneal neurodegenerative changes detected by CCM could be an early biomarker of diabetic polyneuropathy. For studies quantifying corneal neurodegenerative changes by CCM, we did the first three of the four subgroup analyses done for OCT studies.

Changes in neurodegenerative variables were summarised for the retina, the optic nerve head, and the cornea, with summary point estimate from randomeffects meta-analyses and $95 \%$ CIs. The variables were ranked according to the size of the difference between individuals with and without diabetes. Negative values

\begin{tabular}{|c|c|c|}
\hline & Quality criteria & $\begin{array}{l}\text { Number of publications } \\
\text { scored "Yes" }\end{array}$ \\
\hline Added by authors & Consecutive or randomly selected patients? & $12^{30,31,60-69}$ \\
\hline Delphi list* & Were inclusion criteria specified? & $30^{17,29-31,42,43,46-69}$ \\
\hline Delphi list* & Were exclusion criteria specified? & $28^{1,29-31,43,46-48,50-69}$ \\
\hline Added by authors & Were groups similar with respect to age and sex? & $13^{29,30,43,48,50,55,57,62,63,64,66,68,69}$ \\
\hline Delphi list & $\begin{array}{l}\text { Were point estimates and measures of variability } \\
\text { presented for the primary outcome measures? }\end{array}$ & $30^{17,29-31,42,43,46-69}$ \\
\hline Considered for Delphi list & Was calculation of statistical power reported? & $5^{47,62,65-67}$ \\
\hline \multicolumn{3}{|c|}{ *Item split into inclusion and exclusion criteria. } \\
\hline
\end{tabular}

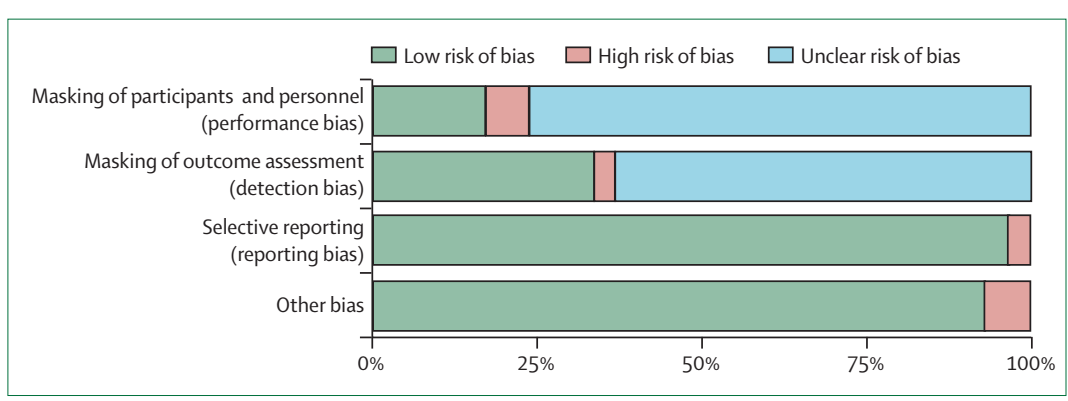

Figure 3: Risk of bias graph: review authors' judgments about each risk of bias item presented as percentages across all included studies

The following domains were assessed. (1) Were data collectors masked with respect to the identity of the patient and medical and neurological results of subjects (performance bias)? (2) Were outcome assessors masked with respect to the identity of patients and medical and neurological results of patients (detection bias)? (3) Were reports of the study free of selective outcome reporting (reporting bias)? (4) Was the study apparently free of other factors that could put it at risk of bias (selection bias, attrition bias, or other bias)?

indicate that the neuronal variable is decreased in individuals with diabetes compared with those without diabetes or that the neuronal variable is decreased in individuals with diabetic retinopathy or polyneuropathy compared with those with diabetes without diabetic retinopathy or polyneuropathy. In all analyses, the weighted mean value and weighted SD of the age and duration of diabetes were calculated for both groups. Heterogeneity between studies was addressed with a statistical $\chi^{2}$ test and $I^{2}$ test. If heterogeneity was present ( $\chi^{2}$ test: $p<0.05$ or $I^{2}$ test $\geq 30 \%$ ), we investigated whether all values of the difference between diabetes and no diabetes pointed in the same direction. If not all studies pointed in the same direction, we reported how many did and tried to find an explanation for the heterogeneity.

\section{Findings}

\section{Selected studies}

4546 articles were identified through database searching. After removing duplicates, 3434 articles were screened. Only 73 unique articles assessed ocular neurodegenerative changes in individuals with diabetes. Two additional records were identified through other sources. Finally, 30 articles met our inclusion criteria (figure 4). 13 articles only reported on individuals with type 1 diabetes $(n=871)$, 16 only reported on individuals with type 2 diabetes 


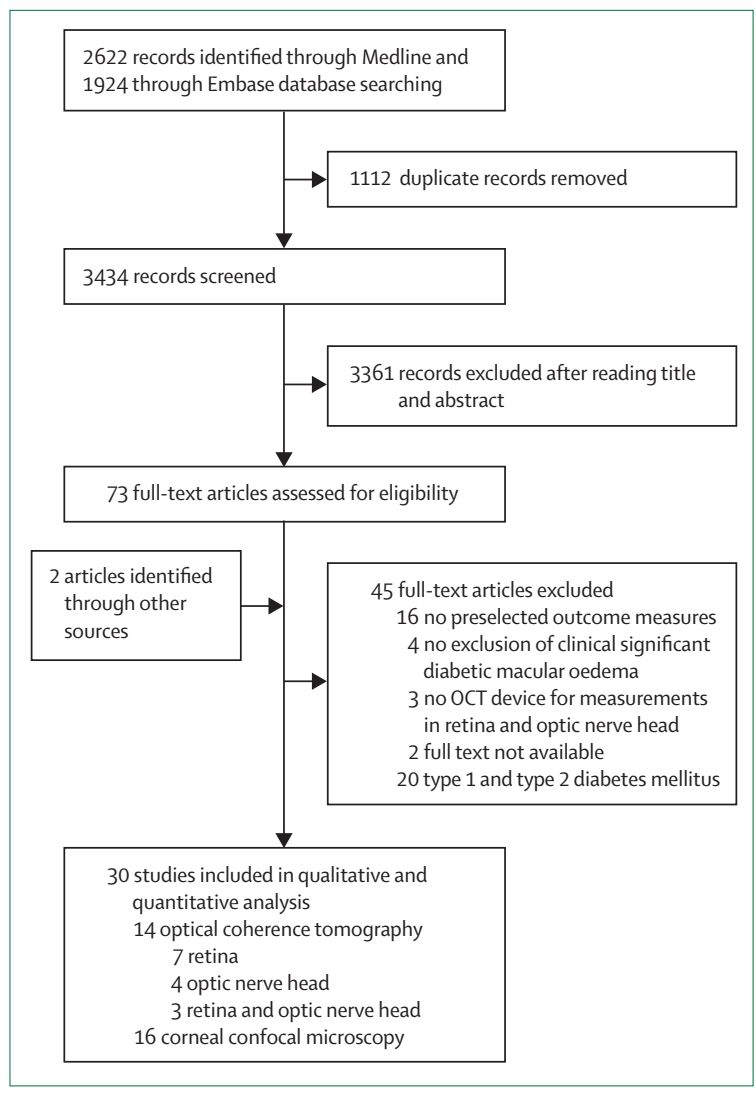

Figure 4: Flow diagram of study selection

$(\mathrm{n}=1359)$, and one study reported on type 1 and type 2 diabetes separately ( $\mathrm{n}=25$ and $\mathrm{n}=18$, respectively). 31 neurodegenerative variables were analysed. Characteristics of the included studies are shown in appendix pp 22-51. 14 studies used OCT and 16 studies used CCM to assess ocular neurodegenerative changes. 28 studies were prospective case series and two were prospective longitudinal studies.

\section{Quality assessment}

Information about consecutiveness of the sample was insufficient in 18 of 30 studies. . $^{1729,42,43,46-59}$ One study selected participants randomly. ${ }^{60}$ In two of 30 studies, reasons for exclusion were not reported. ${ }^{42,49}$ The selection criteria were heterogeneous among studies. Ten studies excluded significant media opacities, ${ }^{29-31,52-54,59,61-63}$ ten studies excluded glaucoma, ${ }^{29-31,52-55,59,63,64} 11$ studies excluded corneal disease, ${ }^{36,47,48,54,56-58,60,62,65,66}$ and 11 studies excluded for neuropathy attributable to causes other than diabetes. ${ }^{17,43,47,48,50,51,56,58,65-67} 13$ of 30 studies included healthy age-matched and sex-matched control

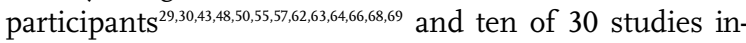
cluded only age-matched control participants. $31,42,46,49,51,53,54,56,59,65$ In some studies, other prognostic indicators also did not differ significantly between both groups: HDL cholesterol $(\mathrm{n}=1)^{43}$ and triglyceride concentrations $\mathrm{s}^{43,51,55,63} \quad(\mathrm{n}=4)$, vision $^{46,53}(\mathrm{n}=2)$, refractive error ${ }^{61}(\mathrm{n}=1)$, mean intraocular pressure $^{46,60,64}(n=3)$, axial length ${ }^{61}(n=1)$, central corneal thickness $^{64}(\mathrm{n}=1)$, urinary albumin:creatinine ratio ${ }^{51,63}$ $(n=2)$, serum creatinine ${ }^{63}(n=1)$, waist circumference ${ }^{67}$ $(\mathrm{n}=1), \mathrm{BMI}^{51,67}(\mathrm{n}=2)$, weight ${ }^{67}(\mathrm{n}=1)$, height ${ }^{67}(\mathrm{n}=1)$, systolic and diastolic blood pressure ${ }^{51,55,63,67,68}(\mathrm{n}=5)$, smoking ${ }^{67,68}$ $(n=2)$, and alcohol $^{67}(n=1)$. All studies reported point estimates for the outcome measures. In 22 of 30 studies, the SD was mentioned. Three studies reported the mean difference with $95 \% \mathrm{CIs},{ }^{29-31}$ four studies reported the SE of the mean value, ${ }^{50-52,56}$ and one study reported the median with IQR ${ }^{68}$ Calculation of statistical power was reported in five studies. ${ }^{47,62,65-67}$ Quality assessment of the included articles is shown in appendix pp 22-51. Table 1 shows the quality assessment across studies.

\section{Risk of bias in included studies}

Risk of bias among the included articles is presented in detail in appendix pp 22-51. Figure 3 shows the risk of bias graph. In five of 30 included studies the data collectors were masked ${ }^{42,56,62,65,67}$ and in ten studies the outcome assessors were masked. ${ }^{17,29,31,42,43,57,58,62,65,67}$ One report did not include all expected outcomes. ${ }^{52} 28$ studies seemed to be free of other sources of bias. Two studies had few female participants ${ }^{17,55}$-in one of these all participants were aged between 60 and 75 years..$^{55}$

\section{Outcome analyses and investigation of heterogeneity}

Table 2 shows the number of studies, number of individuals with and without diabetes, mean age, and duration of diabetes and tables 3 and 4 show numerical data for the neuronal variables. In the results presented in the following sections, we mainly report the presence (not the absence) of significant differences only; we found no heterogeneity in estimates reported unless stated otherwise. Graphical data, and $\chi^{2}$ and $I^{2}$ values for heterogeneity, are shown in full in appendix pp 4-21. Table 5 summarises the results of our analyses and their clinical implications.

\section{Retinal neurodegenerative changes assessed by OCT}

Compared with individuals without diabetes, individuals with type 1 diabetes had a significantly thinner retinal nerve fibre layer and photoreceptor layers (table 3, appendix p 4). ${ }^{30,31,63,68,69}$ Compared with individuals without diabetes, individuals with type 2 diabetes showed a significantly thinner retinal nerve fibre layer, ganglion cell layer, inner plexiform layer, inner nuclear layer, outer plexiform layer, and photoreceptor layers (table 3). For these estimates, heterogeneity was moderate for the ganglion cell layer and substantial for the inner plexiform layer. Despite this heterogeneity, all studies showed a lower value in individuals with type 2 diabetes compared with those without diabetes (appendix p 5). ${ }^{29,46,53,55,59,61}$

In individuals with type 1 diabetes without retinopathy, none of the intraretinal layer thicknesses were signi- 


\begin{tabular}{|c|c|c|c|c|c|c|c|c|c|c|c|c|c|c|}
\hline & \multicolumn{7}{|c|}{ Type 1 diabetes vs controls } & \multicolumn{7}{|c|}{ Type 2 diabetes vs controls } \\
\hline & \multicolumn{4}{|c|}{ Type 1 diabetes } & \multicolumn{3}{|l|}{ Controls } & \multicolumn{4}{|c|}{ Type 2 diabetes } & \multicolumn{3}{|l|}{ Controls } \\
\hline & $\begin{array}{l}\text { Studies } \\
\text { (n) }\end{array}$ & $\begin{array}{l}\text { Individuals } \\
\text { (n) }\end{array}$ & $\begin{array}{l}\text { Age } \\
\text { (years) }\end{array}$ & $\begin{array}{l}\text { Duration } \\
\text { of } \\
\text { diabetes } \\
\text { (years) }\end{array}$ & $\begin{array}{l}\text { Individuals } \\
\text { (n) }\end{array}$ & $\begin{array}{l}\text { Age } \\
\text { (years) }\end{array}$ & $\begin{array}{l}\text { Duration } \\
\text { of diabetes } \\
\text { (years) }\end{array}$ & $\begin{array}{l}\text { Studies } \\
\text { (n) }\end{array}$ & $\begin{array}{l}\text { Individuals } \\
\text { (n) }\end{array}$ & $\begin{array}{l}\text { Age } \\
\text { (years) }\end{array}$ & $\begin{array}{l}\text { Duration } \\
\text { of } \\
\text { diabetes } \\
\text { (years) }\end{array}$ & $\begin{array}{l}\text { Individuals } \\
\text { (n) }\end{array}$ & $\begin{array}{l}\text { Age } \\
\text { (years) }\end{array}$ & $\begin{array}{l}\text { Duration } \\
\text { of } \\
\text { diabetes } \\
\text { (years) }\end{array}$ \\
\hline \multicolumn{15}{|c|}{ Retinal neurodegenerative changes assessed by OCT } \\
\hline $\begin{array}{l}\text { Diabetes vs no } \\
\text { diabetes }\end{array}$ & 5 & 329 & $\begin{array}{c}31 \cdot 7 \\
(10 \cdot 8)\end{array}$ & $\begin{array}{l}13 \cdot 7 \\
(7 \cdot 7)\end{array}$ & 200 & $\begin{array}{l}34 \cdot 0 \\
(11 \cdot 7)\end{array}$ & NA & 6 & 761 & $\begin{array}{l}60 \cdot 7 \\
(8 \cdot 3)\end{array}$ & $\begin{array}{l}10 \cdot 4 \\
(6 \cdot 2)\end{array}$ & 282 & $\begin{array}{l}59 \cdot 5 \\
(10 \cdot 9)\end{array}$ & NA \\
\hline $\begin{array}{l}\text { Diabetes without DR } \\
\text { vs no diabetes }\end{array}$ & 5 & 183 & $\begin{array}{l}30 \cdot 1 \\
(11 \cdot 1)\end{array}$ & $\begin{array}{l}10 \cdot 6 \\
(7 \cdot 2)\end{array}$ & 200 & $\begin{array}{l}34 \cdot 0 \\
(11 \cdot 7)\end{array}$ & NA & 5 & 278 & $\begin{array}{l}59 \cdot 1 \\
(8 \cdot 8)\end{array}$ & $\begin{array}{l}9 \cdot 3 \\
(7 \cdot 1)\end{array}$ & 254 & $\begin{array}{l}60 \cdot 2 \\
(11 \cdot 1)\end{array}$ & NA \\
\hline $\begin{array}{l}\text { Diabetes with DR vs } \\
\text { diabetes without DR }\end{array}$ & 5 & 145 & $\begin{array}{l}33 \cdot 6 \\
(8 \cdot 9)\end{array}$ & $\begin{array}{l}17 \cdot 6 \\
(7 \cdot 6)\end{array}$ & 183 & $\begin{array}{l}30 \cdot 1 \\
(11 \cdot 1)\end{array}$ & $\begin{array}{l}10 \cdot 6 \\
(7 \cdot 2)\end{array}$ & 3 & 73 & $\begin{array}{l}63 \cdot 8 \\
(6 \cdot 8)\end{array}$ & $\begin{array}{l}13 \cdot 2 \\
(7 \cdot 1)\end{array}$ & 176 & $\begin{array}{l}63 \cdot 2 \\
(7 \cdot 9)\end{array}$ & $\begin{array}{l}7 \cdot 7 \\
(6 \cdot 7)\end{array}$ \\
\hline \multicolumn{15}{|c|}{ Neurodegenerative changes around the optic nerve head assessed by OCT } \\
\hline $\begin{array}{l}\text { Diabetes vs no } \\
\text { diabetes }\end{array}$ & 1 & 77 & $\begin{array}{l}35 \\
(29-42)^{*}\end{array}$ & $\begin{array}{l}10 \\
(9-14)^{*}\end{array}$ & 31 & $\begin{array}{l}46 \\
(25-50)^{*}\end{array}$ & NA & 6 & 333 & $\begin{array}{l}56 \cdot 5 \\
(8 \cdot 5)\end{array}$ & $\begin{array}{l}11 \cdot 2 \\
(7 \cdot 7)\end{array}$ & 193 & $\begin{array}{l}54 \cdot 1 \\
(11 \cdot 3)\end{array}$ & NA \\
\hline $\begin{array}{l}\text { Diabetes without DR } \\
\text { vs no diabetes }\end{array}$ & 1 & 54 & $\begin{array}{l}35 \\
(29-42)^{*}\end{array}$ & $\begin{array}{l}10 \\
(9-14)^{*}\end{array}$ & 31 & $\begin{array}{l}46 \\
(25-50)^{*}\end{array}$ & NA & 4 & 157 & $\begin{array}{l}54 \cdot 8 \\
(10 \cdot 3)\end{array}$ & $\begin{array}{c}7 \\
(6 \cdot 6)\end{array}$ & 119 & $\begin{array}{c}53 \\
(13 \cdot 5)\end{array}$ & NA \\
\hline $\begin{array}{l}\text { Diabetes with DR vs } \\
\text { diabetes without DR }\end{array}$ & 1 & 23 & $\begin{array}{l}35 \\
(29-42)^{*}\end{array}$ & $\begin{array}{l}10 \\
(9-14)^{*}\end{array}$ & 54 & $\begin{array}{l}35 \\
(29-42)^{*}\end{array}$ & $\begin{array}{l}10 \\
(9-14)^{*}\end{array}$ & 2 & 56 & $\begin{array}{l}56 \cdot 4 \\
(7 \cdot 2)\end{array}$ & $\begin{array}{l}10 \cdot 7 \\
(6 \cdot 1)\end{array}$ & 55 & $\begin{array}{l}59 \cdot 7 \\
(10 \cdot 6)\end{array}$ & $\begin{array}{l}4 \cdot 8 \\
(4 \cdot 4)\end{array}$ \\
\hline $\begin{array}{l}\text { Diabetes with DPN vs } \\
\text { no diabetes }\end{array}$ & NA & NA & NA & NA & NA & NA & NA & 1 & 82 & $\begin{array}{l}60 \cdot 5 \\
(6 \cdot 4)\end{array}$ & $\begin{array}{l}13 \cdot 6 \\
(9 \cdot 1)\end{array}$ & 24 & $\begin{array}{l}59 \cdot 1 \\
(7 \cdot 2)\end{array}$ & NA \\
\hline \multicolumn{15}{|c|}{ Corneal neurodegenerative changes assessed by CCM } \\
\hline $\begin{array}{l}\text { Diabetes vs no } \\
\text { diabetes }\end{array}$ & 9 & 698 & $\begin{array}{l}44 \cdot 5 \\
(14 \cdot 5)\end{array}$ & $\begin{array}{l}22 \cdot 1 \\
(13 \cdot 7)\end{array}$ & 434 & $\begin{array}{l}44 \\
(15 \cdot 0)\end{array}$ & NA & 8 & 580 & $\begin{array}{l}59 \cdot 8 \\
(8 \cdot 2)\end{array}$ & $\begin{array}{l}11 \cdot 4 \\
(6 \cdot 8)\end{array}$ & 252 & $\begin{array}{l}57 \cdot 9 \\
(9 \cdot 4)\end{array}$ & NA \\
\hline $\begin{array}{l}\text { Diabetes without } \\
\text { DPN vs no diabetes }\end{array}$ & 7 & 456 & $\begin{array}{l}41 \cdot 6 \\
(15 \cdot 1)\end{array}$ & $\begin{array}{l}18 \cdot 8 \\
(13 \cdot 8)\end{array}$ & 409 & $\begin{array}{l}43 \cdot 8 \\
(15 \cdot 4)\end{array}$ & NA & 1 & 23 & $\begin{array}{l}48 \cdot 1 \\
(10 \cdot 6)\end{array}$ & $\begin{array}{l}5 \cdot 8 \\
(5 \cdot 8)\end{array}$ & 28 & $\begin{array}{l}50 \cdot 2 \\
(7 \cdot 4)\end{array}$ & NA \\
\hline $\begin{array}{l}\text { Diabetes with DPN vs } \\
\text { diabetes without DPN }\end{array}$ & 6 & 315 & $\begin{array}{l}49 \cdot 8 \\
(14 \cdot 0)\end{array}$ & $\begin{array}{l}25 \cdot 6 \\
(14 \cdot 5)\end{array}$ & 431 & $\begin{array}{l}41 \cdot 7 \\
(14 \cdot 9)\end{array}$ & $\begin{array}{l}19 \cdot 1 \\
(14 \cdot 0)\end{array}$ & 1 & 55 & $\begin{array}{l}55 \cdot 8 \\
(1.9)\end{array}$ & $\begin{array}{l}9 \cdot 3 \\
(1 \cdot 8)\end{array}$ & 23 & $\begin{array}{l}48 \cdot 1 \\
(10 \cdot 6)\end{array}$ & $\begin{array}{l}5 \cdot 8 \\
(5 \cdot 8)\end{array}$ \\
\hline
\end{tabular}

ficantly different than in individuals without diabetes (table 3, appendix p 6). ${ }^{30,31,63,68,69}$ By contrast, individuals with type 2 diabetes without diabetic retinopathy showed a significant reduction in retinal nerve fibre layer thickness compared with individuals without diabetes, although these results were derived from only one study (table 3, appendix p 7)..$^{29,46,53,55,61}$

Compared with individuals with type 1 diabetes without retinopathy, individuals with type 1 diabetes and retinopathy showed a significant reduction in the thickness of the fovea, the retinal nerve fibre layer, ganglion cell layer, mean ganglion cell layer and inner plexiform layer, and inner nuclear layer (table 3, appendix p 8). ${ }^{30,31,63,68,69}$ Compared with individuals with type 2 diabetes without retinopathy, individuals with type 2 diabetes and retinopathy showed a significant reduction of the inner plexiform layer in one study (table 3, appendix p 9)..$^{29,46,55}$

\section{Neurodegenerative changes around the optic nerve head assessed by OCT}

Only one study compared retinal nerve fibre layer thicknesses in individuals with type 1 diabetes to those in individuals without diabetes. In this study, the inferior and mean retinal nerve fibre layer thicknesses were significantly increased (table 3 , appendix p 10). ${ }^{68}$ Compared with individuals without diabetes, individuals with type 2 diabetes showed a significant decrease in the thickness of the superior and the inferior retinal nerve fibre layers (table 3). Moderate heterogeneity was noted for both estimates (appendix p 11). ${ }^{46,52-54,61,64}$

In individuals with type 1 diabetes without retinopathy, the inferior, temporal, and mean retinal nerve fibre layer thicknesses were significantly increased compared with individuals without diabetes in one study (table 3 , appendix p 12).${ }^{68}$ Compared with individuals without diabetes, individuals with type 2 diabetes without retinopathy showed a significant reduction in mean retinal nerve fibre layer thickness (table 3, appendix p 13). ${ }^{46,53,54,61}$

Compared with individuals with type 1 diabetes without retinopathy, individuals with type 1 diabetes and retinopathy showed a significant decrease of the thickness of the inferior, nasal, temporal, and mean retinal nerve fibre layer in one study (table 3, appendix p 14). ${ }^{68}$ Compared with individuals with type 2 diabetes without retinopathy, individuals with type 2 diabetes and 


\begin{tabular}{|c|c|c|c|c|c|c|}
\hline & \multicolumn{2}{|l|}{ Diabetes vs no diabetes } & \multicolumn{2}{|c|}{ Diabetes without $D R$ vs no diabetes } & \multicolumn{2}{|c|}{ Diabetes with $D R$ vs diabetes without $D R$} \\
\hline & Type 1 diabetes & Type 2 diabetes & Type 1 diabetes & Type 2 diabetes & Type 1 diabetes & Type 2 diabetes \\
\hline \multicolumn{7}{|c|}{ Retinal neurodegenerative changes assessed by OCT } \\
\hline Central fovea, $\mu \mathrm{m}$ & $7.31(-1.59$ to $16 \cdot 20)$ & $3.09(-5.44$ to 11.63$)$ & $9.00(-4 \cdot 48$ to $22 \cdot 48)$ & $-1.36(-6.28$ to $3 \cdot 56)$ & $-3.00(-16.74$ to $10 \cdot 74)$ & $3.00(-9 \cdot 22$ to $15 \cdot 22)$ \\
\hline Fovea, $\mu \mathrm{m}$ & $-1.12(-6.00$ to 3.77$)$ & $1.14(-8.94$ to 11.22$)$ & $0.91(-1.92$ to 3.73$)$ & $-7.49(-20.15$ to $5 \cdot 18)$ & $-7.64(-12.41 \text { to }-2.88)^{*}$ & $12 \cdot 36(-10 \cdot 66$ to $35 \cdot 38)$ \\
\hline $\begin{array}{l}\text { Pericentral RNFL, } \\
\mu \mathrm{m}\end{array}$ & $-0.63(-1.39$ to 0.13$)$ & $-1.29(-2 \cdot 24 \text { to }-0.33)^{*}$ & $-0.06(-0.93$ to 0.80$)$ & $-0.90(-1.96$ to 0.16$)$ & $-1.36(-2 \cdot 44 \text { to }-0.28)^{*}$ & $-1.00(-2.38$ to 0.38$)$ \\
\hline Pericentral GCL, $\mu \mathrm{m}$ & $-1.78(-8 \cdot 15$ to $4 \cdot 59)$ & $-3.43(-6.43 \text { to }-0.42)^{*}$ & $1 \cdot 40(-2 \cdot 30$ to $5 \cdot 10)$ & $-2 \cdot 10(-4 \cdot 80$ to 0.60$)$ & $-6.50(-10.97 \text { to }-2.03)^{*}$ & $-3.10(-6.76$ to 0.56$)$ \\
\hline Pericentral IPL, $\mu \mathrm{m}$ & $-1 \cdot 11(-3 \cdot 17$ to 0.94$)$ & $-2.99(-5.93 \text { to }-0.05)^{*}$ & $0.00(-2.18$ to $2 \cdot 18)$ & $-1.50(-3 \cdot 14$ to 0.14$)$ & $-2 \cdot 10(-4 \cdot 37$ to 0.17$)$ & $-3 \cdot 00(-4 \cdot 78 \text { to }-1 \cdot 22)^{*}$ \\
\hline $\begin{array}{l}\text { Pericentral } \\
\mathrm{GCL}+\mathrm{IPL}, \mu \mathrm{m}\end{array}$ & $-2 \cdot 57(-7 \cdot 67$ to $2 \cdot 52)$ & NA & $-0.20(-3.29$ to 2.89$)$ & NA & $-5.22(-9.83 \text { to }-0.61)^{*}$ & NA \\
\hline Pericentral INL, $\mu \mathrm{m}$ & $-0.60(-1.82$ to 0.62$)$ & $-1.24(-2 \cdot 34 \text { to }-0.14)^{*}$ & $0.32(-0.85$ to 1.50$)$ & $-1.40(-2.83$ to 0.03$)$ & $-2.04(-3.43 \text { to }-0.64)^{*}$ & $0.40(-1.35$ to $2 \cdot 15)$ \\
\hline Pericentral OPL, $\mu \mathrm{m}$ & $0.78(0.01$ to 1.54$)$ & $-0.79(-1.76$ to 0.19$)$ & $0.63(-1.03$ to 2.29$)$ & $-0.70(-1.99$ to 0.59$)$ & 0.24 (-1.91 to 2.39$)$ & $-0.20(-1.69$ to 1.29$)$ \\
\hline $\begin{array}{l}\text { Pericentral ONL+IS, } \\
\mu \mathrm{m}\end{array}$ & $-2.44(-4.60 \text { to }-0.28)^{*}$ & $-3.66(-6.38 \text { to }-0.95)^{*}$ & $-1.99(-5.02$ to 1.03$)$ & $-3 \cdot 10(-6.71$ to 0.51$)$ & -0.89 (-4.56 to 2.79$)$ & $-1 \cdot 30(-5.88$ to 3.28$)$ \\
\hline Pericentral OS, $\mu \mathrm{m}$ & $0.53(-0.19$ to 1.24$)$ & $-0.56(-1.25$ to 0.12$)$ & $0.14(-0.59$ to 0.88$)$ & $-0.80(-1.68$ to 0.08$)$ & $0.92(-0.00$ to 1.85$)$ & $0.60(-0.57$ to 1.77$)$ \\
\hline Pericentral RPE, $\mu \mathrm{m}$ & $1.11(0.13$ to 2.08$)$ & $0.10(-0.61$ to 0.81$)$ & $1.60(0.36$ to 2.84$)$ & 0.10 (-0.83 to 1.03$)$ & $-1.00(-2.41$ to 0.41$)$ & $0.00(-1.14$ to 1.14$)$ \\
\hline $\begin{array}{l}\text { Pericentral retinal } \\
\text { thickness, } \mu \mathrm{m}\end{array}$ & $-2 \cdot 20(-6.95$ to 2.56$)$ & $2.01(-8.56$ to 12.57$)$ & $-0.67(-8.19$ to 6.85$)$ & 2.01 (-8.56 to 12.57$)$ & $-3.91(-10.73$ to 2.91$)$ & NA \\
\hline $\begin{array}{l}\text { Peripheral RNFL, } \\
\mu \mathrm{m}\end{array}$ & $-1.42(-2 \cdot 67 \text { to }-0.17)^{*}$ & $-2.55(-4.13 \text { to }-0.96)^{*}$ & $-0.85(-2.44$ to 0.75$)$ & $-2 \cdot 20(-4 \cdot 16 \text { to }-0 \cdot 24)^{*}$ & $-1.52(-3.93$ to 0.90$)$ & $-1.00(-3.63$ to 1.63$)$ \\
\hline Peripheral GCL, $\mu \mathrm{m}$ & $-0.09(-1.80$ to 1.63$)$ & -0.46 (-2.28 to 1.37$)$ & $0.60(-1.07$ to 2.27$)$ & $0.30(-0.98$ to 1.58$)$ & $-1.80(-4.23$ to 0.63$)$ & $-1.90(-3.96$ to 0.16$)$ \\
\hline Peripheral IPL, $\mu \mathrm{m}$ & $-1 \cdot 23(-3 \cdot 19$ to 0.73$)$ & $-1 \cdot 74(-4 \cdot 77$ to $1 \cdot 30)$ & $-0.20(-2.13$ to 1.73$)$ & $-0.20(-1.64$ to 1.24$)$ & -2.00 (-4.11 to 0.11$)$ & $-3 \cdot 10(-4 \cdot 77 \text { to }-1 \cdot 43)^{*}$ \\
\hline $\begin{array}{l}\text { Peripheral GCL+IPL, } \\
\mu \mathrm{m}\end{array}$ & $-1 \cdot 12(-2 \cdot 85$ to 0.60$)$ & NA & $-0.36(-2.08$ to 1.36$)$ & NA & $-1.78(-4 \cdot 10$ to 0.54$)$ & NA \\
\hline Peripheral INL, $\mu \mathrm{m}$ & $-0.29(-1.05$ to 0.47$)$ & $-0.82(-1.79$ to 0.15$)$ & $0.27(-0.50$ to 1.04$)$ & $-0.40(-1.36$ to 0.56$)$ & $-1.30(-2.20 \text { to }-0.40)^{*}$ & $-1.00(-2.15$ to 0.15$)$ \\
\hline Peripheral OPL, $\mu \mathrm{m}$ & $0.08(-0.38$ to 0.53$)$ & $-0.62(-1.19 \text { to }-0.04)^{*}$ & $0.05(-0.54$ to 0.63$)$ & $-0.40(-1.12$ to 0.32$)$ & $0.13(-0.91$ to 1.16$)$ & $-0.60(-1.51$ to 0.31$)$ \\
\hline $\begin{array}{l}\text { Peripheral ONL+IS, } \\
\mu \mathrm{m}\end{array}$ & $-1.14(-2.69$ to 0.40$)$ & $-1.99(-3.95 \text { to }-0.03)^{*}$ & $-1.32(-3.62$ to 0.98$)$ & $-1.30(-4.05$ to 1.45$)$ & $0.36(-2.23$ to 2.95$)$ & $-1.40(-4.58$ to 1.78$)$ \\
\hline Peripheral OS, $\mu \mathrm{m}$ & $0.47(-0.11$ to 1.05$)$ & $-0.22(-0.85$ to 0.40$)$ & 0.78 (0.09 to 1.47$)$ & $-0.30(-1.09$ to 0.49$)$ & $-0.80(-2.18$ to 0.58$)$ & $0.20(-0.85$ to 1.25$)$ \\
\hline Peripheral RPE, $\mu \mathrm{m}$ & $1.12(0.41$ to 1.83$)$ & $0.08(-0.50$ to 0.65$)$ & $0.80(-0.16$ to 1.76$)$ & $0.00(-0.73$ to 0.73$)$ & $0.70(-0.46$ to 1.86$)$ & $0.20(-0.75$ to 1.15$)$ \\
\hline $\begin{array}{l}\text { Peripheral retinal } \\
\text { thickness, } \mu \mathrm{m}\end{array}$ & $2 \cdot 23(-0.69$ to $5 \cdot 16)$ & NA & $1.43(-2.56$ to 5.42$)$ & NA & $1.63(-4 \cdot 15$ to $7 \cdot 41)$ & NA \\
\hline \multicolumn{7}{|c|}{ Neurodegenerative changes around the optic nerve head assessed by OCT } \\
\hline $\begin{array}{l}\text { Nasal RNFL } \\
\text { thickness, } \mu \mathrm{m}\end{array}$ & $-2.06(-9.12$ to 4.99$)$ & $-3 \cdot 50(-10 \cdot 32$ to 3.32$)$ & $1.50(-0.04$ to 3.04$)$ & $-3 \cdot 50(-10 \cdot 32$ to $3 \cdot 32)$ & $-7 \cdot 20(-9 \cdot 24$ to $-5 \cdot 16) \dagger$ & NA \\
\hline $\begin{array}{l}\text { Superior RNFL } \\
\text { thickness, } \mu \mathrm{m}\end{array}$ & $0.79(-1.38$ to 2.96$)$ & $-7.69(-14 \cdot 30$ to -1.08$) \dagger$ & $1.70(-1.13$ to 4.53$)$ & $-4 \cdot 99(-11 \cdot 16$ to $1 \cdot 18)$ & $-2 \cdot 20(-5 \cdot 13$ to 0.73$)$ & $-12 \cdot 30(-24 \cdot 21$ to $-0 \cdot 39) \dagger$ \\
\hline $\begin{array}{l}\text { Temporal RNFL } \\
\text { thickness, } \mu \mathrm{m}\end{array}$ & $3.28(-0.84$ to $7 \cdot 39)$ & $-0.50(-8.00$ to 7.00$)$ & $5 \cdot 30(3 \cdot 70$ to $6 \cdot 90)$ & $-0.50(-8.00$ to 7.00$)$ & $-4 \cdot 20(-6 \cdot 16$ to $-2 \cdot 24) \dagger$ & NA \\
\hline $\begin{array}{l}\text { Inferior RNFL } \\
\text { thickness, } \mu \mathrm{m}\end{array}$ & $19.69(5 \cdot 67$ to $33 \cdot 70)$ & $-6.23(-11.28$ to -0.63$) \dagger$ & 26.80 (24.67 to 28.93$)$ & -3.99 (-11.59 to 3.61$)$ & $-14.30(-17.01$ to -11.59$) \dagger$ & $-12.00(-23.61$ to -0.39$) \dagger$ \\
\hline $\begin{array}{l}\text { Mean RNFL } \\
\text { thickness, } \mu \mathrm{m}\end{array}$ & $6.43(0.75$ to 12.11$)$ & $-2.96(-6.35$ to 0.44$)$ & 9.30 (7.69 to $10 \cdot 91)$ & $-5 \cdot 36(-7 \cdot 13$ to $-3 \cdot 58) \dagger$ & $-5.80(-7.47$ to -4.13$) \dagger$ & $-5 \cdot 30(-11.67$ to 1.08$)$ \\
\hline
\end{tabular}

retinopathy showed a significant decrease in the thickness of the superior and inferior retinal nerve fibre layers in one study (table 3, appendix p 15). ${ }^{46,54}$

One study noted an association between diabetic polyneuropathy and inferior retinal nerve fibre layer thinning in individuals with type 2 diabetes $(p=0 \cdot 03)$, particularly in individuals with moderate and severe polyneuropathy $(\mathrm{p}<0 \cdot 005) .{ }^{52}$
Corneal neurodegenerative changes assessed by CCM

Compared with individuals without diabetes, individuals with type 1 diabetes showed a significant reduction of nerve density and nerve length in the subbasal nerve plexus of the cornea (table 4). Substantial heterogeneity was present for all variables. All but two studies showed a lower value for the variables measured in individuals with diabetes (appendix p 16)..$^{17,42,43,47,50,58,65-67}$ Compared with individuals 


\begin{tabular}{|c|c|c|c|c|c|c|}
\hline & \multicolumn{2}{|l|}{ Diabetes vs no diabetes } & \multicolumn{2}{|c|}{ Diabetes without DPN vs no diabetes } & \multicolumn{2}{|c|}{ Diabetes with DPN vs diabetes without DPN } \\
\hline & Type 1 diabetes & Type 2 diabetes & Type 1 diabetes & Type 2 diabetes & Type 1 diabetes & Type 2 diabetes \\
\hline Nerve branch density, $/ \mathrm{mm}^{2}$ & $-19.38(-27.52 \text { to }-11.24)^{*}$ & $-14.32(-18.86 \text { to }-9.79)^{*}$ & $-7.74(-14.13 \text { to }-1.34)^{*}$ & $-1.10(-4 \cdot 22$ to 2.02$)$ & $-9.61(-15.60 \text { to }-3.62)^{*}$ & $-2.83(-6.16$ to 0.50$)$ \\
\hline Nerve fibre density, $/ \mathrm{mm}^{2}$ & $-9.33(-15 \cdot 28 \text { to }-3 \cdot 38)^{*}$ & $-10.36(-13.09 \text { to }-7.64)^{*}$ & $-2.68(-5.56$ to 0.20$)$ & $-5.80(-8.06 \text { to }-3.54)^{*}$ & $-8.72(-13.54 \text { to }-3.90)^{*}$ & $-4.17(-7.87 \text { to }-0.47)^{*}$ \\
\hline Nerve fibre length, $\mathrm{mm} / \mathrm{mm}^{2}$ & $-5.05(-7.27 \text { to }-2.84)^{*}$ & $-5.09(-6.55 \text { to }-3.62)^{*}$ & $-2.58(-3.94 \text { to }-1.21)^{*}$ & $-4.00(-5.93 \text { to }-2.07)^{*}$ & $-4.12(-5.43 \text { to }-2.82)^{*}$ & $-1.23(-2.19 \text { to }-0.27)^{*}$ \\
\hline Nerve fibre tortuosity & $-1.55(-3.24$ to 0.15$)$ & $0.48(0.30 \text { to } 0.65)^{*}$ & $-1.86(-3.95$ to 0.24$)$ & $0.63(0.43 \text { to } 0.83)^{*}$ & $0.74(-1.21$ to 2.69$)$ & $0.00(-0.15$ to 0.15$)$ \\
\hline
\end{tabular}

\begin{tabular}{|c|c|c|c|c|c|}
\hline & $\begin{array}{l}\text { Number } \\
\text { of studies } \\
\text { (type } 1 \\
\text { diabetes: } \\
\text { type } 2 \\
\text { diabetes) }\end{array}$ & Image location in the eye & Comparison & Results & Clinical implications \\
\hline OCT & $5: 6$ & Retinal layers & Diabetes vs no diabetes & $\begin{array}{l}\text { Type } 1 \text { diabetes: thinner RNFL and photoreceptor } \\
\text { layer; type } 2 \text { diabetes: thinner RNFL, GCL, and } \\
\text { photoreceptor layer }\end{array}$ & $\begin{array}{l}\text { OCT can detect retinal neurodegenerative changes in } \\
\text { the diabetic eye }\end{array}$ \\
\hline OCT & $5: 5$ & Retinal layers & $\begin{array}{l}\text { Diabetes without DR vs no } \\
\text { diabetes }\end{array}$ & $\begin{array}{l}\text { Type } 1 \text { diabetes: no significant changes; type } 2 \\
\text { diabetes: thinner RNFL }\end{array}$ & $\begin{array}{l}\text { Thinning of retinal layers might be an early sign of } \\
\text { diabetic retinopathy in type } 2 \text { diabetes }\end{array}$ \\
\hline OCT & $5: 3$ & Retinal layers & $\begin{array}{l}\text { Diabetes with DR vs } \\
\text { diabetes without DR }\end{array}$ & $\begin{array}{l}\text { Type } 1 \text { diabetes: thinner RNFL and GCL; type } 2 \\
\text { diabetes: thinner GCL }\end{array}$ & $\begin{array}{l}\text { Thinning of retinal layers is more evident when } \\
\text { diabetic retinopathy is present }\end{array}$ \\
\hline OCT & $1: 6$ & $\begin{array}{l}\text { RNFL around the optic } \\
\text { nerve head }\end{array}$ & Diabetes vs no diabetes & $\begin{array}{l}\text { Type } 1 \text { diabetes: thicker RNFL; type } 2 \text { diabetes: thinner } \\
\text { superior and inferior RNFL }\end{array}$ & $\begin{array}{l}\text { OCT can detect neurodegenerative changes around } \\
\text { the optic nerve head in type } 2 \text { diabetes }\end{array}$ \\
\hline OCT & $1: 4$ & $\begin{array}{l}\text { RNFL around the optic } \\
\text { nerve head }\end{array}$ & $\begin{array}{l}\text { Diabetes without DR vs no } \\
\text { diabetes }\end{array}$ & $\begin{array}{l}\text { Type } 1 \text { diabetes: thicker RNFL; type } 2 \text { diabetes: thinner } \\
\text { mean RNFL }\end{array}$ & $\begin{array}{l}\text { RNFL thinning around the optic nerve head could be } \\
\text { an early sign of diabetic retinopathy in type } 2 \text { diabetes }\end{array}$ \\
\hline OCT & $1: 2$ & $\begin{array}{l}\text { RNFL around the optic } \\
\text { nerve head }\end{array}$ & $\begin{array}{l}\text { Diabetes with DR vs } \\
\text { diabetes without DR }\end{array}$ & $\begin{array}{l}\text { Type } 1 \text { diabetes: thinner inferior, nasal, temporal, and } \\
\text { mean RNFL; type } 2 \text { diabetes: thinner superior and } \\
\text { inferior RNFL }\end{array}$ & $\begin{array}{l}\text { RNFL thinning around the optic nerve head is more } \\
\text { evident when diabetic retinopathy is present }\end{array}$ \\
\hline OCT & $0: 1$ & $\begin{array}{l}\text { RNFL around the optic } \\
\text { nerve head }\end{array}$ & $\begin{array}{l}\text { Diabetes with DPN vs no } \\
\text { diabetes }\end{array}$ & $\begin{array}{l}\text { Type } 1 \text { diabetes: no data; type } 2 \text { diabetes: inferior RNFL } \\
\text { thinner with increasing severity of DPN }\end{array}$ & $\begin{array}{l}\text { RNFL thinning around the optic nerve head is related } \\
\text { to the severity of diabetic polyneuropathy in type } 2 \\
\text { diabetes }\end{array}$ \\
\hline $\mathrm{CCM}$ & $9: 8$ & $\begin{array}{l}\text { Subbasal nerve plexus of } \\
\text { the cornea }\end{array}$ & Diabetes vs no diabetes & $\begin{array}{l}\text { Type } 1 \text { diabetes: reduced nerve density and length; } \\
\text { type } 2 \text { diabetes: reduced nerve density and length, and } \\
\text { increased tortuosity }\end{array}$ & $\begin{array}{l}\text { CCM can detect corneal neurodegenerative changes in } \\
\text { the diabetic eye }\end{array}$ \\
\hline CCM & $7: 1$ & $\begin{array}{l}\text { Subbasal nerve plexus of } \\
\text { the cornea }\end{array}$ & $\begin{array}{l}\text { Diabetes without DPN vs } \\
\text { no diabetes }\end{array}$ & $\begin{array}{l}\text { Type } 1 \text { diabetes: reduced nerve density and length; } \\
\text { type } 2 \text { diabetes: reduced nerve density and length, and } \\
\text { increased tortuosity }\end{array}$ & $\begin{array}{l}\text { Corneal neurodegenerative changes could be an early } \\
\text { sign of diabetic polyneuropathy }\end{array}$ \\
\hline CCM & $6: 1$ & $\begin{array}{l}\text { Subbasal nerve plexus of } \\
\text { the cornea }\end{array}$ & $\begin{array}{l}\text { Diabetes with DPN vs } \\
\text { diabetes without DPN }\end{array}$ & $\begin{array}{l}\text { Type } 1 \text { diabetes: reduced nerve density and length; } \\
\text { type } 2 \text { diabetes: reduced nerve density and length }\end{array}$ & $\begin{array}{l}\text { Corneal neurodegenerative changes are more evident } \\
\text { when diabetic polyneuropathy is present }\end{array}$ \\
\hline
\end{tabular}

without diabetes, individuals with type 2 diabetes showed a significant reduction in nerve density and nerve length. The tortuosity showed a small increase in individuals with type 2 diabetes (table 4). Substantial heterogeneity was present for all variables. For nerve density and nerve length all studies showed a lower value in individuals with type 2 diabetes, and for tortuosity all studies showed a higher value in individuals with diabetes (appendix p 17). ${ }^{48,49,51,56-58,60,62}$

Compared with individuals without diabetes, individuals with type 1 diabetes without polyneuropathy showed significant reduction in nerve branch density and nerve length. There was substantial heterogeneity for both variables. However, there was a reduction of the nerve branch density in all but one study, ${ }^{50}$ which had a point estimate of $1 \cdot 7$, whereas the other point estimates ranged from $-5 \cdot 1$ to $-21 \cdot 8$. There was also a reduction of the nerve fibre length in all but one study, which had a point estimate of $0 \cdot 97$, whereas the other point estimates ranged from $-1 \cdot 7$ to $-5 \cdot 6$ (appendix p 18). $17,47,50,58,65-67$ Compared with individuals without diabetes, individuals with type 2 diabetes without polyneuropathy showed a significant reduction in nerve density and nerve length in one study. The tortuosity showed a small increase (appendix p 19). ${ }^{51}$

Compared with individuals with type 1 diabetes without polyneuropathy, individuals with type 1 diabetes and polyneuropathy showed a significant reduction of nerve 
density and nerve length. Substantial heterogeneity was present for all variables. However, all studies showed a lower value in individuals with type 1 diabetes and polyneuropathy (appendix p 20)..$^{17,47,50,65-67}$ Compared with individuals with type 2 diabetes without polyneuropathy, individuals with type 2 diabetes and polyneuropathy showed a significant reduction in nerve fibre density and nerve length. Moderate heterogeneity was present for nerve length and substantial heterogeneity was present for the nerve fibre density (appendix $\mathrm{p} 21$ ). ${ }^{51}$

\section{Discussion}

In this paper, we have summarised the features of OCT and CCM, and systematically reviewed studies of ocular neurodegenerative changes as assessed with these imaging techniques in adults with type 1 or type 2 diabetes. To our knowledge, this is the first systematic review to evaluate these changes in the retina, the optic nerve head, and the cornea. We noted that ocular neurodegenerative changes occur in individuals with diabetes, even at an early stage when diabetic retinopathy or polyneuropathy as assessed with conventional methods are not present. These findings suggest that thinning of retinal layers is an early sign of diabetic retinopathy, and that changes in corneal nerve fibres are an early sign of diabetic polyneuropathy. Ocular neurodegenerative changes are more evident when diabetic retinopathy or polyneuropathy is present.

OCT shows thinning of the photoreceptor layers and could reflect the loss of photoreceptors, the only neurons that are directly sensitive to light. The intermediate cells transmit the neural signs from the photoreceptors to the ganglion cells. Loss of these intermediate cells could induce thinning of the outer plexiform layer, the inner nuclear layer, and the inner plexiform layer. In the ganglion cells, neural signs take the form of action potentials. Loss of these ganglion cells could explain thinning of the ganglion cell layer measured by OCT. The axons of ganglion cells form the retinal nerve fibre layer and travel towards the optic nerve head. Loss of these nerve fibres that connect the retina with the brain could explain thinning of the retinal nerve fibre layer in the retina and around the optic nerve head, as detected by OCT. All these neurons are involved in the transmission of neural signs to the brain. ${ }^{11}$ Loss or disconnection of retinal neuronal cells might cause functional deficits. ${ }^{27}$

The presence of ocular neurodegeneration in diabetes could change our view on diabetic retinopathy, which is traditionally deemed a microvascular complication of diabetes. Loss of neuronal and glial cells has been suggested to be caused by chronic hyperglycaemia, oxidative stress, and accumulation of advanced glycation end products that directly affect metabolism in the retina. ${ }^{72,73}$ Animal and human studies have indicated that these insults can result in neuronal apoptosis (including of neurons and photoreceptors), loss of ganglion cell bodies, glial reactivity, and thinning of the neuronal layers in the retina. ${ }^{749}$
Neuronal and glial cells interact with vascular cells in the retina forming a neurovascular unit. Molecular changes in diabetes affect all these cells in the retina, leading to a disruption of the neurovascular unit. ${ }^{80}$ It has been hypothesised that damage to neuronal and glial cells precedes vascular changes. ${ }^{74}$ An increase of the concentration of glutamate and the loss of neuroprotective factors result in an increase of vascular endothelial growth factor leading to a breakdown of the blood-retinal barrier. Neuronal death and glial dysfunction might also cause microvascular changes. Furthermore, a decreased number or dysfunction of endothelial progenitor cells reduces the remodelling capacity of the microvessels, thus further increasing microvascular and neurodegenerative changes. Finally, inflammatory parameters might also contribute to microvascular and neurodegenerative changes. ${ }^{74}$

Structural changes as shown by OCT could explain functional changes of the retina in individuals with diabetes. These functional changes can be assessed by perimetry, ${ }^{81,82}$ contrast sensitivity test, ${ }^{83}$ colour vision test, ${ }^{84}$ dark adaptation test, ${ }^{85}$ multifocal electroretinography, ${ }^{86}$ electrophysiology, ${ }^{87}$ and microperimetry. ${ }^{88}$ Some of these functional changes are already present before microvascular abnormalities are visible. In particular, multifocal electroretinographic abnormalities can predict which retinal locations will develop microvascular changes in the near future..$^{89-92}$

OCT and CCM are non-invasive techniques with a high reproducibility. ${ }^{14-18,93,94}$ OCT is already used to assess thinning of the retinal neuronal layers in glaucoma and other neurodegenerative diseases, such as multiple sclerosis. OCT is also widely used in diabetes care to assess the presence of diabetic macular oedema and is therefore readily available to assess neurodegenerative changes in individuals with diabetes. OCT could therefore be used more widely in the clinic to help in the detection of retinal neurodegeneration, to define at-risk patients and to plan preventive therapy before overt vascular lesions develop. This technique could also be of use to monitor progression of diabetic retinopathy and to assess therapeutic efficacy of existing or new treatment methods. ${ }^{32-34}$ It also seems of relevance in clinical practice in the detection of diabetic polyneuropathy. However, repeated OCT measurements could be needed to reduce measurement error.

CCM is mostly used by ophthalmologists who specialise in corneal or refractive surgery. Generalised use will mean more training and increased costs. However, such investment could be worthwhile: CCM could clinically help in the diagnosis of diabetic polyneuropathy in a noninvasive way $y^{4,95}$ and might predict future polyneuropathy before changes are detected by electrophysiology and vibratory perception, ${ }^{11}$ even in individuals with impaired glucose tolerance. ${ }^{96}$ In two longitudinal studies, the onset of diabetic polyneuropathy was predicted by CCM. ${ }^{65,97}$ Additionally, CCM can be used to monitor progression of diabetic polyneuropathy, ${ }^{65,97}$ to assess therapeutic efficacy 
of existing or new treatment methods, and to detect regeneration of corneal nerves after intensive treatment of diabetes. ${ }^{41-43}$ CCM can therefore be used in all four clinical domains - diagnosis, prognosis, monitoring, and assessment of treatment effects.

Some methodological issues deserve discussion. Methods of the analysis and inclusion criteria were specified and documented in a protocol, but this protocol was not prospectively registered. In addition, our results could be affected by publication bias, but this could not be assessed because of the small number of included studies. Finally, we did not adjust our analysis for multiple testing. However, our results are in line with the biological and clinical plausibility that diabetes causes ocular neurodegenerative changes.

Some issues at study level also need to be addressed. We detected heterogeneity for some outcome variables, which was mostly due to variation in the effect sizes between studies, rather than a difference in the direction of the effect. This variation can partly be explained by a dose-effect relation between severity of diabetic retinopathy or polyneuropathy in the different studies, and the associated ocular neurodegenerative changes. Only a few of the studies we reviewed mentioned statistical power, and the number of individuals in several studies was small. Most of the studies included were prospective case series, and a few did not mention exclusion of significant media opacities. Finally, we included studies that used different types of OCT devices. In view of the small number of studies, it is not possible to conduct a metaregression analysis to assess whether the type of OCT device affected our results. However, only differences in retinal layer thickness were reported, implying that the same type of OCT was used for comparison between individuals with and without diabetes in every study (in view of the fact that different OCT devices cannot be used interchangeably).

Before incorporation of OCT and CCM to routine screening programmes for diabetic retinopathy and diabetic polyneuropathy, their incremental benefit needs to be determined in addition to conventional clinical investigations. CCM could detect ocular neurodegenerative changes earlier than does OCT, but a head-to-head study is needed to compare these approaches. Large prospective studies are in progress to determine which neurodegenerative parameters should be used in clinical screening for diabetic retinopathy and diabetic polyneuropathy, to develop standard protocols for image analysis, and to establish reference values for clinical use. ${ }^{33,67,98}$ Possible causes and risk factors for the occurrence of ocular neurodegenerative changes-eg, duration of diabetes, glycaemic control, hypertension, age, and sex-need to be studied in depth. Moreover, future studies should address the relation of ocular neurodegenerative changes with diabetic autonomic neuropathy, ${ }^{99}$ cognitive decline, and white matter loss. Finally, costeffective studies for more widespread use of OCT and $\mathrm{CCM}$ in the clinical setting are needed.

\section{Contributors}

All authors participated in the structure of the review. EEBDC did the study selection, data extraction, and risk of bias assessment. In case of doubt, JSAGS was consulted. EEBDC and JSAGS prepared the first draft and the subsequent versions. All authors commented on the drafts, contributed to writing, and approved the final version.

\section{Declaration of of interests}

We declare no competing interests.

\section{Acknowledgments}

This research was supported by grant 122047 from Fonds NutsOhra, the Netherlands.

\section{References}

1 Dyck PJ, Norell JE, Tritschler H, et al. Challenges in design of multicenter trials: end points assessed longitudinally for change and monotonicity. Diabetes Care 2007; 30: 2619-25.

2 Fletcher EL, Phipps JA, Ward MM, Puthussery T, Wilkinson-Berka JL. Neuronal and glial cell abnormality as predictors of progression of diabetic retinopathy. Curr Pharm Des 2007; 13: 2699-712

3 Perkins BA, Olaleye D, Zinman B, Bril V. Simple screening tests for peripheral neuropathy in the diabetes clinic. Diabetes Care 2001; 24: 250-56.

4 Perkins BA, Orszag A, Ngo M, Ng E, New P, Bril V. Prediction of incident diabetic neuropathy using the monofilament examination: a 4-year prospective study. Diabetes Care 2010; 33: 1549-54.

5 Barber AJ, Lieth E, Khin SA, Antonetti DA, Buchanan AG, Gardner TW. Neural apoptosis in the retina during experimental and human diabetes. Early onset and effect of insulin. J Clin Invest 1998; 102: 783-91.

6 Carrasco E, Hernandez C, Miralles A, Huguet P, Farres J, Simo R. Lower somatostatin expression is an early event in diabetic retinopathy and is associated with retinal neurodegeneration. Diabetes Care 2007; 30: 2902-08.

7 Carrasco E, Hernandez C, de Torres I, Farres J, Simo R. Lowered cortistatin expression is an early event in the human diabetic retina and is associated with apoptosis and glial activation. Mol Vis 2008; 14: $1496-502$.

8 Garcia-Ramirez M, Hernandez C, Villarroel M, et al. Interphotoreceptor retinoid-binding protein (IRBP) is downregulated at early stages of diabetic retinopathy. Diabetologia 2009; 52: 2633-41.

9 Arezzo JC. The use of electrophysiology for the assessment of diabetic neuropathy. Neurosci Res Commun 1997; 21: 13-23.

10 Dyck PJ, Overland CJ, Low PA, et al. Signs and symptoms versus nerve conduction studies to diagnose diabetic sensorimotor polyneuropathy: Cl vs. NPhys trial. Muscle Nerve 2010; 42: 157-64.

11 Sumner CJ, Sheth S, Griffin JW, Cornblath DR, Polydefkis M. The spectrum of neuropathy in diabetes and impaired glucose tolerance. Neurology 2003; 60: 108-11.

12 de Neeling JN, Beks PJ, Bertelsmann FW, Heine RJ, Bouter LM. Sensory thresholds in older adults: reproducibility and reference values. Muscle Nerve 1994; 17: 454-61.

13 Allgeier S, Maier S, Mikut R, et al. Mosaicking the subbasal nerve plexus by guided eye movements. Invest Ophthalmol Vis Sci 2014; 55: 6082-89.

14 Bressler SB, Edwards AR, Chalam KV, et al. Reproducibility of spectral-domain optical coherence tomography retinal thickness measurements and conversion to equivalent time-domain metrics in diabetic macular edema. JAMA Ophthalmol 2014; 132: 1113-22.

15 Petropoulos IN, Manzoor T, Morgan P, et al. Repeatability of in vivo corneal confocal microscopy to quantify corneal nerve morphology. Cornea 2013; 32: e83-89.

16 Efron N, Edwards K, Roper N, et al. Repeatability of measuring corneal subbasal nerve fiber length in individuals with type 2 diabetes. Eye Contact Lens 2010; 36: 245-48.

17 Hertz P, Bril V, Orszag A, et al. Reproducibility of in vivo corneal confocal microscopy as a novel screening test for early diabetic sensorimotor polyneuropathy. Diabet Med 2011; 28: 1253-60. 
18 Villain MA, Greenfield DS. Peripapillary nerve fiber layer thickness measurement reproducibility using optical coherence tomography. Ophthalmic Surg Lasers Imaging 2003; 34: 33-37.

19 Ehnes A, Wenner Y, Friedburg C, et al. Optical coherence tomography (OCT) device independent intraretinal layer segmentation. Transl Vis Sci Technol 2014; 3: 1.

20 Garvin MK, Abramoff MD, Wu X, Russell SR, Burns TL, Sonka M. Automated 3-D intraretinal layer segmentation of macular spectral-domain optical coherence tomography images. IEEE Trans Med Imaging 2009; 28: 1436-47.

21 Petropoulos IN, Alam U, Fadavi H, et al. Rapid automated diagnosis of diabetic peripheral neuropathy with in vivo corneal confocal microscopy. Invest Ophthalmol Vis Sci 2014; 55: 2071-78.

22 Scarpa F, Grisan E, Ruggeri A. Automatic recognition of corneal nerve structures in images from confocal microscopy. Invest Ophthalmol Vis Sci 2008; 49: 4801-07.

23 Midena E, Cortese M, Miotto S, Gambato C, Cavarzeran F, Ghirlando A. Confocal microscopy of corneal sub-basal nerve plexus: a quantitative and qualitative analysis in healthy and pathologic eyes. J Refract Surg 2009; 25: S125-30.

24 Dabbah MA, Graham J, Petropoulos I, Tavakoli M, Malik RA. Dual-model automatic detection of nerve-fibres in corneal confocal microscopy images. Med Image Comput Comput Assist Interv 2010; 13: $300-07$.

25 Dabbah MA, Graham J, Petropoulos IN, Tavakoli M, Malik RA. Automatic analysis of diabetic peripheral neuropathy using multi-scale quantitative morphology of nerve fibres in corneal confocal microscopy imaging. Med Image Anal 2011; 15: 738-47.

26 Meijering E, Jacob M, Sarria JC, Steiner P, Hirling H, Unser M. Design and validation of a tool for neurite tracing and analysis in fluorescence microscopy images. Cytometry A 2004; 58: 167-76.

27 van Dijk HW, Verbraak FD, Stehouwer M, et al. Association of visual function and ganglion cell layer thickness in patients with diabetes mellitus type 1 and no or minimal diabetic retinopathy. Vision Res 2011; 51: 224-28.

28 Fischer MD, Huber G, Beck SC, et al. Noninvasive, in vivo assessment of mouse retinal structure using optical coherence tomography. PLoS One 2009; 4: e7507.

29 van Dijk HW, Verbraak FD, Kok PH, et al. Early neurodegeneration in the retina of type 2 diabetic patients. Invest Ophthalmol Vis Sci 2012; 53: 2715-19.

30 van Dijk HW, Kok PH, Garvin M, et al. Selective loss of inner retinal layer thickness in type 1 diabetic patients with minimal diabetic retinopathy. Invest Ophthalmol Vis Sci 2009; 50: 3404-09.

31 van Dijk HW, Verbraak FD, Kok PH, et al. Decreased retinal ganglion cell layer thickness in patients with type 1 diabetes. Invest Ophthalmol Vis Sci 2010; 51: 3660-65.

32 Scott IU, Jackson GR, Quillen DA, Klein R, Liao J, Gardner TW. Effect of doxycycline vs placebo on retinal function and diabetic retinopathy progression in mild to moderate nonproliferative diabetic retinopathy: a randomized proof-of-concept clinical trial. JAMA Ophthalmol 2014; 132: 1137-42.

33 Simo R, Hernandez C. Neurodegeneration is an early event in diabetic retinopathy: therapeutic implications. Br J Ophthalmol 2012; 96: $1285-90$.

34 Sugimoto M, Sasoh M, Ido M, Narushima C, Uji Y. Retinal nerve fiber layer decrease during glycemic control in type 2 diabetes. J Ophthalmol 2010; 2010: 569215.

35 Guthoff RF, Zhivov A, Stachs O. In vivo confocal microscopy, an inner vision of the cornea-a major review. Clin Experiment Ophthalmol 2009; 37: 100-17.

36 Pritchard N, Edwards K, Efron N. Non-contact laser-scanning confocal microscopy of the human cornea in vivo. Cont Lens Anterior Eye 2014; 37: 44-48.

37 Jalbert I, Stapleton F, Papas E, Sweeney DF, Coroneo M. In vivo confocal microscopy of the human cornea. Br J Ophthalmol 2003; 87: 225-36.

38 Rosenberg ME, Tervo TM, Immonen IJ, Muller LJ, Gronhagen-Riska C, Vesaluoma MH. Corneal structure and sensitivity in type 1 diabetes mellitus. Invest Ophthalmol Vis Sci 2000; 41: 2915-21.

39 Malik RA, Kallinikos P, Abbott CA, et al. Corneal confocal microscopy: a non-invasive surrogate of nerve fibre damage and repair in diabetic patients. Diabetologia 2003; 46: 683-88.
40 Efron N. The Glenn A. Fry award lecture 2010: Ophthalmic markers of diabetic neuropathy. Optom Vis Sci 2011; 88: 661-83.

41 Tavakoli M, Kallinikos P, Iqbal A, et al. Corneal confocal microscopy detects improvement in corneal nerve morphology with an improvement in risk factors for diabetic neuropathy. Diabet Med 2011; 28: 1261-67.

42 Mehra S, Tavakoli M, Kallinikos PA, et al. Corneal confocal microscopy detects early nerve regeneration after pancreas transplantation in patients with type 1 diabetes. Diabetes Care 2007; 30: 2608-12

43 Tavakoli M, Mitu-Pretorian M, Petropoulos IN, et al. Corneal confocal microscopy detects early nerve regeneration in diabetic neuropathy after simultaneous pancreas and kidney transplantation. Diabetes 2013; 62: 254-60.

44 Moher D, Liberati A, Tetzlaff J, Altman DG, Group P. Preferred reporting items for systematic reviews and meta-analyses: the PRISMA statement. Ann Intern Med 2009; 151: 264-69.

45 Liberati A, Altman DG, Tetzlaff J, et al. The PRISMA statement for reporting systematic reviews and meta-analyses of studies that evaluate health care interventions: explanation and elaboration. PLoS Med 2009; 6: e1000100.

46 Oshitari T, Hanawa K, Adachi-Usami E. Changes of macular and RNFL thicknesses measured by Stratus OCT in patients with early stage diabetes. Eye (Lond) 2009; 23: 884-89.

47 Ahmed A, Bril V, Orszag A, et al. Detection of diabetic sensorimotor polyneuropathy by corneal confocal microscopy in type 1 diabetes: a concurrent validity study. Diabetes Care 2012; 35: 821-28.

48 Ziegler D, Papanas N, Zhivov A, et al. Early detection of nerve fiber loss by corneal confocal microscopy and skin biopsy in recently diagnosed type 2 diabetes. Diabetes 2014; 63: 2454-63.

49 Chang PY, Carrel H, Huang JS, et al. Decreased density of cornea basal epithelium and subbasal corneal nerve bundle changes in patients with diabetic retinopathy. Am J Ophthalmol 2006; 142: 488-90.

50 Ishibashi F, Okino M, Ishibashi M, et al. Corneal nerve fiber pathology in Japanese type 1 diabetic patients and its correlation with antecedent glycemic control and blood pressure. J Diabetes Investig 2012; 3: 191-98.

51 Ishibashi F, Kojima R, Kawasaki A, Yamanaka E, Kosaka A, Uetake H. Correlation between sudomotor function, sweat gland duct size and corneal nerve fiber pathology in patients with type 2 diabetes mellitus. J Diabetes Investig 2014; 5: 588-96.

52 Shahidi AM, Sampson GP, Pritchard N, et al. Retinal nerve fibre layer thinning associated with diabetic peripheral neuropathy. Diabet Med 2012; 29: e106-11.

53 Verma A, Raman R, Vaitheeswaran K, et al. Does neuronal damage precede vascular damage in subjects with type 2 diabetes mellitus and having no clinical diabetic retinopathy? Ophthalmic Res 2012; 47: 202-07.

54 Lung JC, Swann PG, Wong DS, Chan HH. Global flash multifocal electroretinogram: early detection of local functional changes and its correlations with optical coherence tomography and visual field tests in diabetic eyes. Doc Ophthalmol 2012; 125: 123-35.

55 Asefzadeh B, Fisch BM, Parenteau CE, Cavallerano AA. Macular thickness and systemic markers for diabetes in individuals with no or mild diabetic retinopathy. Clin Experiment Ophthalmol 2008; 36: 455-63.

56 Nitoda E, Kallinikos P, Pallikaris A, et al. Correlation of diabetic retinopathy and corneal neuropathy using confocal microscopy. Curr Eye Res 2012; 37: 898-906.

57 Mocan MC, Durukan I, Irkec M, Orhan M. Morphologic alterations of both the stromal and subbasal nerves in the corneas of patients with diabetes. Cornea 2006; 25: 769-73.

58 Stem MS, Hussain M, Lentz SI, et al. Differential reduction in corneal nerve fiber length in patients with type 1 or type 2 diabetes mellitus. J Diabetes Complications 2014; 28: 658-61.

59 Pires I, Santos AR, Nunes S, Lobo C. Macular thickness measured by stratus optical coherence tomography in patients with diabetes type 2 and mild nonproliferative retinopathy without clinical evidence of macular edema. Ophthalmologica 2013; 229: 181-86.

60 Bitirgen G, Ozkagnici A, Malik RA, Kerimoglu H. Corneal nerve fibre damage precedes diabetic retinopathy in patients with type 2 diabetes mellitus. Diabet Med 2014; 31: 431-38. 
61 Sugimoto M, Sasoh M, Ido M, Wakitani Y, Takahashi C, Uji Y. Detection of early diabetic change with optical coherence tomography in type 2 diabetes mellitus patients without retinopathy. Ophthalmologica 2005; 219: 379-85.

62 De Cilla S, Ranno S, Carini E, et al. Corneal subbasal nerves changes in patients with diabetic retinopathy: an in vivo confocal study. Invest Ophthalmol Vis Sci 2009; 50: 5155-58.

63 Biallosterski C, van Velthoven ME, Michels RP, Schlingemann RO, DeVries JH, Verbraak FD. Decreased optical coherence tomography-measured pericentral retinal thickness in patients with diabetes mellitus type 1 with minimal diabetic retinopathy. Br J Ophthalmol 2007; 91: 1135-38.

64 Toprak I, Yildirim C, Yaylali V. Optic disc topographic analysis in diabetic patients. Int Ophthalmol 2012; 32: 559-64.

65 Dehghani C, Pritchard N, Edwards K, et al. Natural history of corneal nerve morphology in mild neuropathy associated with type 1 diabetes: development of a potential measure of diabetic peripheral neuropathy. Invest Ophthalmol Vis Sci 2014; 55: 7982-90.

66 Sivaskandarajah GA, Halpern EM, Lovblom LE, et al. Structurefunction relationship between corneal nerves and conventional small-fiber tests in type 1 diabetes. Diabetes Care 2013; 36: 2748-55.

67 Pritchard N, Edwards K, Dehghani C, et al. Longitudinal assessment of neuropathy in type 1 diabetes using novel ophthalmic markers (LANDMark): study design and baseline characteristics. Diabetes Res Clin Pract 2014; 104: 248-56.

68 Araszkiewicz A, Zozulinska-Ziolkiewicz D, Meller M, et al. Neurodegeneration of the retina in type 1 diabetic patients. Pol Arch Med Wewn 2012; 122: 464-70.

69 Ciresi A, Amato MC, Morreale D, et al. OCT is not useful for detection of minimal diabetic retinopathy in type 1 diabetes. Acta Diabetol 2010; 47: 259-63.

70 Verhagen AP, de Vet HC, de Bie RA, et al. The Delphi list: a criteria list for quality assessment of randomized clinical trials for conducting systematic reviews developed by Delphi consensus. J Clin Epidemiol 1998; 51: 1235-41.

71 Masland RH. The fundamental plan of the retina. Nat Neurosci 2001; 4: 877-86.

72 Brownlee M. Biochemistry and molecular cell biology of diabetic complications. Nature 2001; 414: 813-20.

73 King GL, Brownlee M. The cellular and molecular mechanisms of diabetic complications. Endocrinol Metab Clin North Am 1996; 25: 255-70.

74 Simo R, Hernandez C, European Consortium for the Early Treatment of Diabetic Retinopathy (EUROCONDOR). Neurodegeneration in the diabetic eye: new insights and therapeutic perspectives. Trends Endocrinol Metab 2014; 25: 23-33.

75 Bogdanov P, Corraliza L, Villena JA, et al. The $\mathrm{db} / \mathrm{db}$ mouse: a useful model for the study of diabetic retinal neurodegeneration. PLoS One 2014; 9: e97302.

76 Tang L, Zhang Y, Jiang Y, et al. Dietary wolfberry ameliorates retinal structure abnormalities in $\mathrm{db} / \mathrm{db}$ mice at the early stage of diabetes. Exp Biol Med (Maywood )2011; 23: 1051-63.

77 Kim SY, Johnson MA, McLeod DS, et al. Retinopathy in monkeys with spontaneous type 2 diabetes. Invest Ophthalmol Vis Sci 2004; 45: 4543-53.

78 Bloodworth JM Jr. Diabetic retinopathy. Diabetes 1962; 11: 1-22.

79 Wolter JR. Diabetic retinopathy. Am J Ophthalmol 1961; 51: 1123-41.

80 Antonetti DA, Klein R, Gardner TW. Diabetic retinopathy. N Engl J Med 2012; 366: 1227-39.

81 Han Y, Adams AJ, Bearse MA Jr, Schneck ME. Multifoca electroretinogram and short-wavelength automated perimetry measures in diabetic eyes with little or no retinopathy. Arch Ophthalmol 2004; 122: 1809-15.
82 Realini T, Lai MQ, Barber L. Impact of diabetes on glaucoma screening using frequency-doubling perimetry. Ophthalmology 2004; 111: $2133-36$

83 Sokol S, Moskowitz A, Skarf B, Evans R, Molitch M, Senior B. Contrast sensitivity in diabetics with and without background retinopathy. Arch Ophthalmol 1985; 103: 51-54.

84 Hardy KJ, Lipton J, Scase MO, Foster DH, Scarpello JH. Detection of colour vision abnormalities in uncomplicated type 1 diabetic patients with angiographically normal retinas. $\mathrm{Br} \mathrm{J} \mathrm{Ophthalmol} 1992$ 76: 461-64.

85 Henson DB, North RV. Dark adaptation in diabetes mellitus. Br J Ophthalmol 1979; 63: 539-41.

86 Klemp K, Sander B, Brockhoff PB, Vaag A, Lund-Andersen H, Larsen $\mathrm{M}$. The multifocal ERG in diabetic patients without retinopathy during euglycemic clamping. Invest Ophthalmol Vis Sci 2005; 46: 2620-26.

87 Bresnick GH. Diabetic retinopathy viewed as a neurosensory disorder. Arch Ophthalmol 1986; 104: 989-90.

88 Vujosevic S, Pilotto E, Bottega E, Benetti E, Cavarzeran F, Midena E. Retinal fixation impairment in diabetic macular edema. Retina 2008 28: $1443-50$

89 Han Y, Bearse MA Jr, Schneck ME, Barez S, Jacobsen CH, Adams AJ. Multifocal electroretinogram delays predict sites of subsequent diabetic retinopathy. Invest Ophthalmol Vis Sci 2004; 45: 948-54.

90 Bearse MA Jr, Adams AJ, Han Y, et al. A multifocal electroretinogram model predicting the development of diabetic retinopathy. Prog Retin Eye Res 2006; 25: 425-48.

91 Ng JS, Bearse MA Jr, Schneck ME, Barez S, Adams AJ. Local diabetic retinopathy prediction by multifocal ERG delays over 3 years Invest Ophthalmol Vis Sci 2008; 49: 1622-28.

92 Harrison WW, Bearse MA Jr, Ng JS, et al. Multifocal electroretinograms predict onset of diabetic retinopathy in adult patients with diabetes. Invest Ophthalmol Vis Sci 2011; 52: 772-27.

93 Hatef E, Khwaja A, Rentiya Z, et al. Comparison of time domain and spectral domain optical coherence tomography in measurement of macular thickness in macular edema secondary to diabetic retinopathy and retinal vein occlusion. J Ophthalmol 2012; 2012: 354783.

94 Schuman JS, Pedut-Kloizman T, Hertzmark E, et al. Reproducibility of nerve fiber layer thickness measurements using optical coherence tomography. Ophthalmology 1996; 103: 1889-98.

95 Tavakoli M, Quattrini C, Abbott C, et al. Corneal confocal microscopy: a novel noninvasive test to diagnose and stratify the severity of human diabetic neuropathy. Diabetes Care 2010; 33: 1792-97.

96 Asghar O, Petropoulos IN, Alam U, et al. Corneal confocal microscopy detects neuropathy in subjects with impaired glucose tolerance. Diabetes Care 2014; 37: 2643-46.

97 Pritchard N, Edwards K, Russell AW, Perkins BA, Malik RA, Efron N. Corneal confocal microscopy predicts 4-year incident peripheral neuropathy in type 1 diabetes. Diabetes Care 2015 38: 671-75.

98 Schram MT, Sep SJ, van der Kallen CJ, et al. The Maastricht Study: an extensive phenotyping study on determinants of type 2 diabetes, its complications and its comorbidities. Eur J Epidemiol 2014; 29: 439-51.

99 Tavakoli M, Begum P, McLaughlin J, Malik RA. CORNEAL confoca microscopy for the diagnosis of diabetic autonomic neuropathy. Muscle Nerve 2014; published online Dec 30. DOI:10.1002/ mus. 24553. 